\title{
OPTIMUM POSITION OF STEEL OUTRIGGER SYSTEM FOR HIGH RISE COMPOSITE BUILDINGS SUBJECTED TO WIND LOADS
}

\author{
Sabrina Fawzia ${ }^{1,{ }^{*}}$ and Tabassum Fatima ${ }^{2}$ \\ ${ }^{1,2}$ Science and Engineering Faculty, School of Civil Engineering and Built Environment, \\ Queensland University of Technology, Brisbane 4000, Queensland, Australia \\ *(Corresponding author: E-mail: sabrina.fawzia@qut.edu.au)
}

Received: 16 January 2015; Revised: 17 June 2015; Accepted: 3 July 2015

\begin{abstract}
The responses of composite buildings under wind loads clearly become more critical as the building becomes taller, less stiff and more lightweight. When the composite building increases in height, the stiffness of the structure becomes more important factor and introduction to belt truss and outrigger system is often used to provide sufficient lateral stiffness to the structure. Most of the research works to date is limited to reinforced concrete building with outrigger system of concrete structure, simple building plan layout, single height of a building, one direction wind and single level of outrigger arrangement. There is a scarcity in research works about the effective position of outrigger level on composite buildings under lateral wind loadings when the building plan layout, height and outrigger arrangement are varied. The aim of this paper is to determine the optimum location of steel belt and outrigger systems by using different arrangement of single and double level outrigger for different size, shape and height of composite building. In this study a comprehensive finite element modelling of composite building prototypes is carried out, with three different layouts (Rectangular, Octagonal and L shaped) and for three different storey (28, 42 and 57-storey). Models are analysed for dynamic cyclonic wind loads with various combination of steel belt and outrigger bracings. It is concluded that the effectiveness of the single and double level steel belt and outrigger bracing are varied based on their positions for different size, shape and height of composite building.
\end{abstract}

Keywords: Steel structure, Lateral deflection, Outriggers, Composite building, Multi-storey, Wind load

DOI: 10.18057/IJASC.2016.12.2.4

\section{INTRODUCTION}

Tall composite building constructions have been rapidly increasing worldwide because of their lightweight and speed of construction. The design of tall structure is usually governed by the lateral loads imposed on the structure. As building gets taller, the structural engineers have been increasingly challenged to achieve structural safety under lateral wind load. The belt and outrigger bracings are commonly used for wind dominated area as one of the structural systems to determine structural safety due to lateral wind load.

Outriggers have been used for approximately four decades although their existence as a structural member has a much longer history. Academic research has limited amount of material on overall performance of composite buildings with steel bracings, however; appreciable amount of literature is present on reinforced concrete, steel structures and very limited on composite structures such as; Nanduri et al [1] used 30 story reinforced concrete building to study the behavior of outrigger, outrigger location optimization and the efficiency of each outrigger when three outriggers are used in the structure. For 30-storey model, the optimum location of the outrigger system is proven to be at the middle height of the structure from the base.

Chung 2010 [2] used reinforced concrete construction with two outrigger-braced core-to-columns building model with height of $300 \mathrm{~m}$ and $36 \mathrm{~m} \times 36 \mathrm{~m}$ horizontal floor dimensions. His work 
principally provided a preliminary guide to assess the performance of outrigger braced system by estimating the restraining moments at the outrigger locations, core base bending moment, the total building deflection, along-wind and crosswind acceleration of a tall building. His study shows that the best location of the outriggers is somewhere at equal distance of the height of the structure from the base.

Kian and Siahaan [3] extrapolated the efficiency of belt-truss and outriggers in concrete high-rise buildings subjected to wind and earthquake loadings. Authors used two dimensional 40- storey model for wind and three dimensional 60-storey model for seismic load analysis. They came up with the optimum location of belt-truss and outriggers with $65 \%$ and $18 \%$ lateral deflection reduction for wind and earthquake loadings respectively.

Hoenderkamp and Bakker [4] presented a graphical method of analysis for tall building frame braced with outriggers and subjected to uniform lateral loadings. Authors have used steel structures for their two dimensional model. They have concluded that behaviour of steel braced frame with outriggers was similar to concrete wall with outriggers beams and further suggested that horizontal deflection and bending moments were influenced by stiffness and therefore; it should be included in the preliminary design of tall structures.

Hoenderkamp [5] derived an analytical method for preliminary design of outrigger braced high-rise shear walls subjected to horizontal loading. He used a two dimensional analytical model of shear wall with outriggers at two levels, one outrigger has a fixed location up the height of the structure, while the second was placed at various location along the model height. He has provided comparison of deflection reduction for a 29-storey model with few combination of two outriggers floors and concluded that the optimum location of the second outrigger was at 0.577 of the height of the building when the first one was placed at the top of the building.

Lee et al [6] focused on deriving the equations for wall-frame structures with outriggers under lateral loads in which the whole structure was idealized as a shear-flexural cantilever and effects of shear deformation of the shear wall and flexural deformation of the frame were considered. Authors have verified the equation by considering the concrete wall-frame building structure under uniform wind loading. Conclusions highlighted that consideration of shear deformations of walls and flexural deformations of frame in analytical formula gave sufficiently accurate results.

Lee et al [7] used wall frame tall building for octagonal plan building in their study. Authors developed simplified model to calculate average stiffness and determined the global behaviour of the buildings.

Taranath $[8,9]$ documented different composite systems, different varieties of composite building and different varieties of lateral reistance system available in the world for composite building.

Rahgozar and Sharifi [10] presented mathematical model for calculation of stresses in columns of combined framed tube, shear core and belt-truss system. He applied his mathematical models to 30, 40 and 50 storey buildings and compared the results with SAP 2000 software for its applicability. He concluded with the best outrigger location at $1 / 4$ th and $1 / 6$ th of the model height. His study was based on pure numerical models and he did not use the actual properties of materials.

In today's tall building engineering, it is a rare event indeed, to come across a building that is regular in plan [8]. Structural engineers are more interested for varieties of plan layout for tall composite building. Moreover it is not difficult to adopt an analytical model based on literature [4, 5 and 6] to obtain the drift and the natural frequencies of the buildings with less efforts for $98 \mathrm{~m}$ 
height but it is not wise to use available analytical model when building height gets bigger. All of the above researches do not consider a comprehensive study of composite building of dissimilar plan layouts of varied heights with different combinations of belt-truss and outriggers under wind dominated area. Different combination of lateral load resisting system i.e. single floor or double floor bracings, with varied plan layouts and assorted heights would results differently.

Therefore; the aim of this paper is to study the behaviour of multi-storey composite buildings when subjected to cyclonic wind loads, calculated in Australian standards domain. Conclusion will be determined by using frequency and deflection results. The assumption of this study is frequency level considered below $1 \mathrm{~Hz}$. As the study is purely based under wind load authors ignored the effects from vibration and damping. P-D effect which should be unimportant in serviceability limit state also ignored in this study.

A detailed parametric study has been carried out by varying heights $(98 \mathrm{~m}, 147 \mathrm{~m}$ and $199.5 \mathrm{~m})$, plans (Rectangular, Octagonal and L-shaped) and number and placement of lateral bracings for commonly used composite building structures in Australia.

\section{PARAMETERS OF STUDY}

The choice of parameters integrated many factors based on aim and objectives of this paper. These include using of locally available construction material, commonly occurring building types and consideration of local general practices. Hence following parameters are selected for this study;

- $\quad$ Model heights;

- $\quad$ Model plan layout;

- Belt-truss and outriggers variations.

\subsection{Models Heights Selection}

The following building heights are selected based on the below considerations:

- $\quad$ The maximum allowable height for the applicability of Australian Standards AS1170.2 [11] is $200 \mathrm{~m}$. Therefore; 57 -storey ( $199.5 \mathrm{~m}$ with $3.5 \mathrm{~m}$ floor to floor height) is chosen to study the effects of wind and seismic loads on maximum given building elevation.

- $\quad 42$-storey $(147.0 \mathrm{~m})$ is most common type of multi-storey rise within the Australian urban environment. Many office and residential buildings are constructed around this height; hence this is an appropriate comparison with the $199.5 \mathrm{~m}$ tall model.

- $\quad 28$-storey is nearly half the height of the 57 storey model, i.e. $98 \mathrm{~m}$ and is selected to establish a comparison and to find out the benefits (if any) of belt-truss and outriggers on such a low elevation.

\subsection{Layout Selection for Models}

The main object in layout selection is to allow maximum variation and maintain distinction. In all models, $\mathrm{Z}$-axis represents the vertical axis, whereas; $\mathrm{X}$-axis and $\mathrm{Y}$-axis are planner axes. The plan layouts selected are;

\subsubsection{Rectangular shaped}

Rectangular model with plan dimensions of $30 \mathrm{~m}$ and $80 \mathrm{~m}$ (Figure $1 \&$ Figure 2 ) is a common shape in Australia because land demarcation is usually rectangular in most of the local municipalities; therefore developers tend to go for this shape of structure. The layout has higher rigidity in one axis 
and less in the other; hence it is relevant to study the lateral load effects and frequency modes of this plan layout.

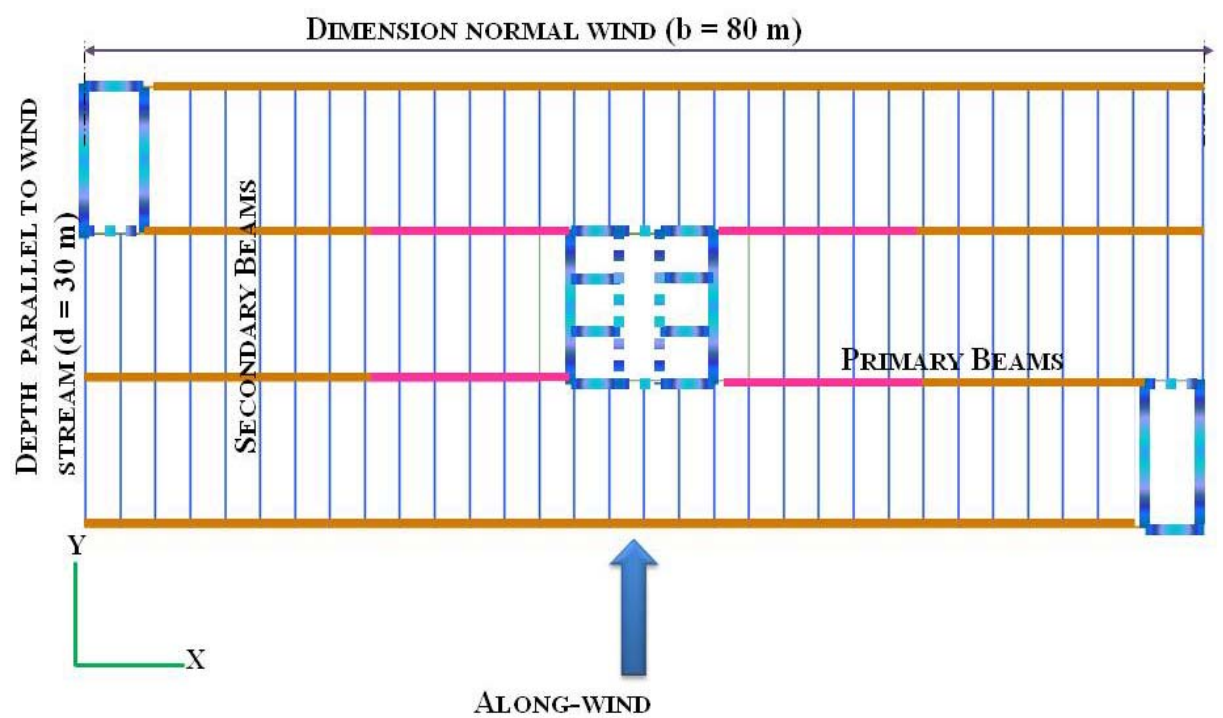

Figure 1. Direction of Wind Rectangular Plan
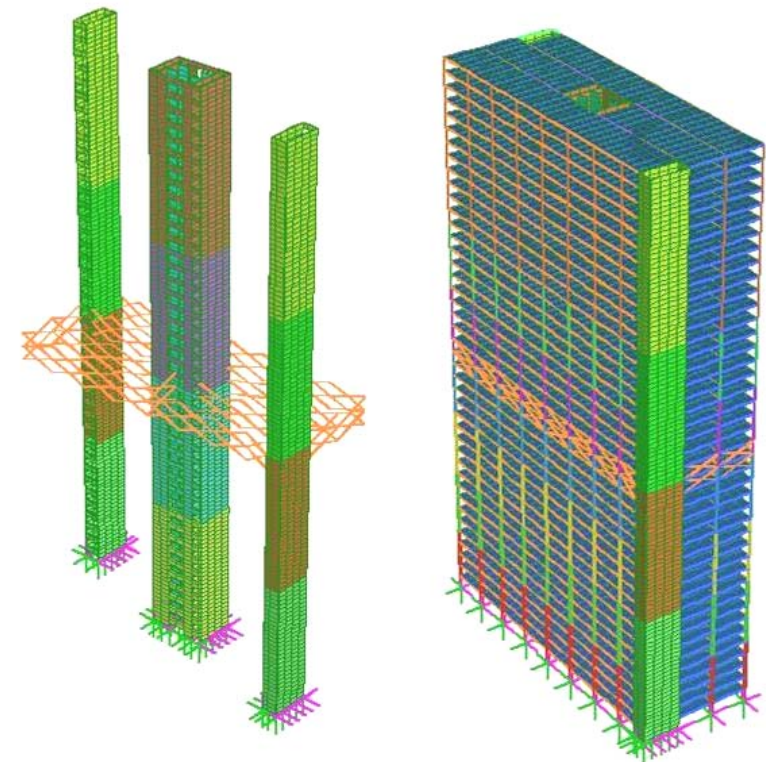

Figure 2. Rectangular Model Elevation (Shear Wall and Full Model)

\subsubsection{Octagonal shape}

This has equal plane dimensions of $60 \mathrm{~m}$ in each direction (Figure 3 and Figure 4) and hence can represent circular and square buildings. However; in square shapes swirling effects can be produced by re-entrant corners. Australian standard AS1170.2 [11] takes account of these effects unless building exceeds the prescribed height and width. This layout is also popular for office building. 


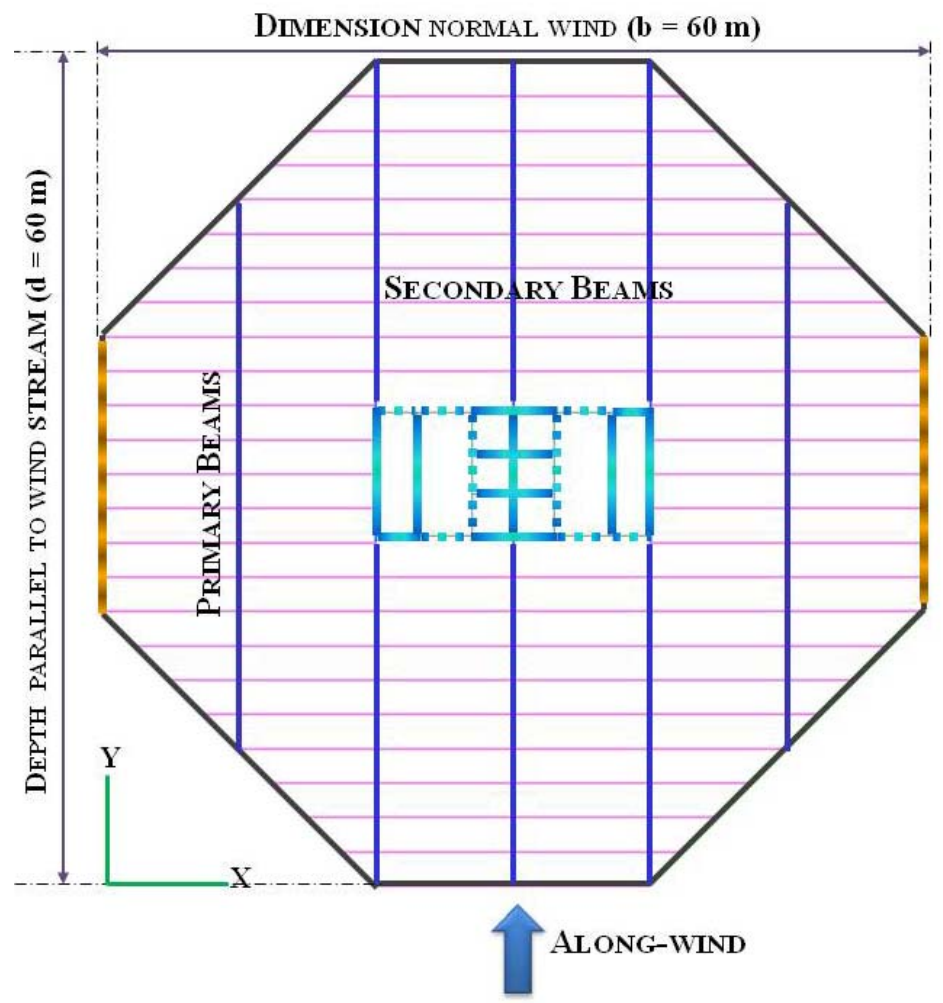

Figure 3. Direction of Wind on Octagonal Layout
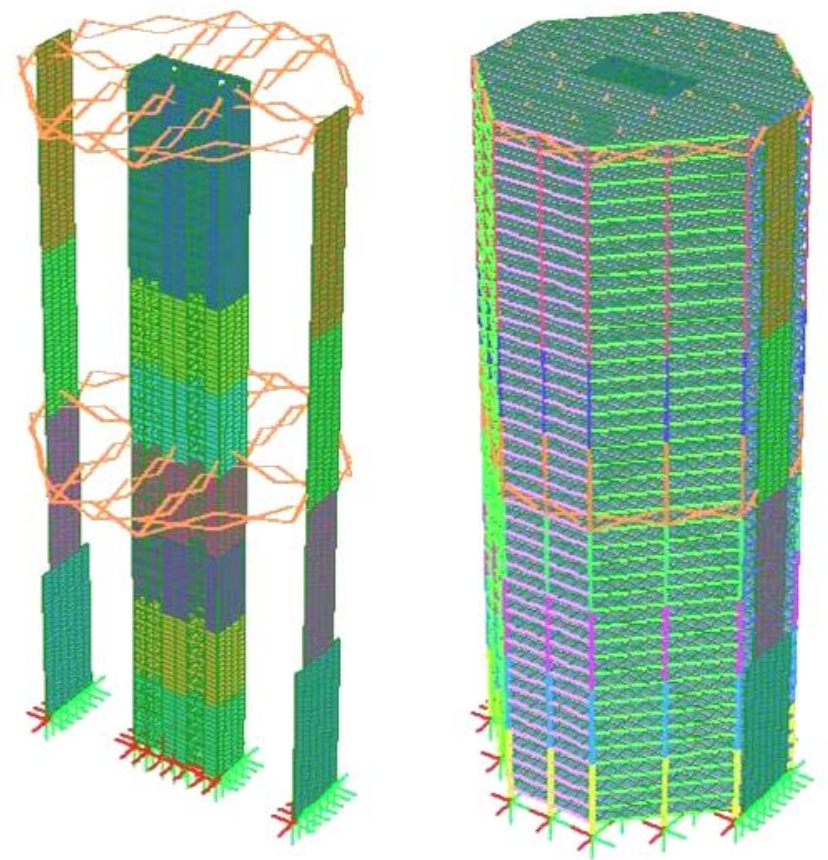

Figure 4. Octagonal Model Elevation (Shear Wall and Full Model)

\subsubsection{L-shaped model}

L-shaped model with plan dimensions of $60 \mathrm{~m}$ and $80 \mathrm{~m}$ is selected to study an extended layout with double core walls in both of its arms (Figure 5 \& Figure 6). The effects of lateral loads on this model 
are studied and compared with the other two less rigid models. The corner wall around the stair well and side walls are needed to stabilise the model and to achieve the desired frequency mode shapes.

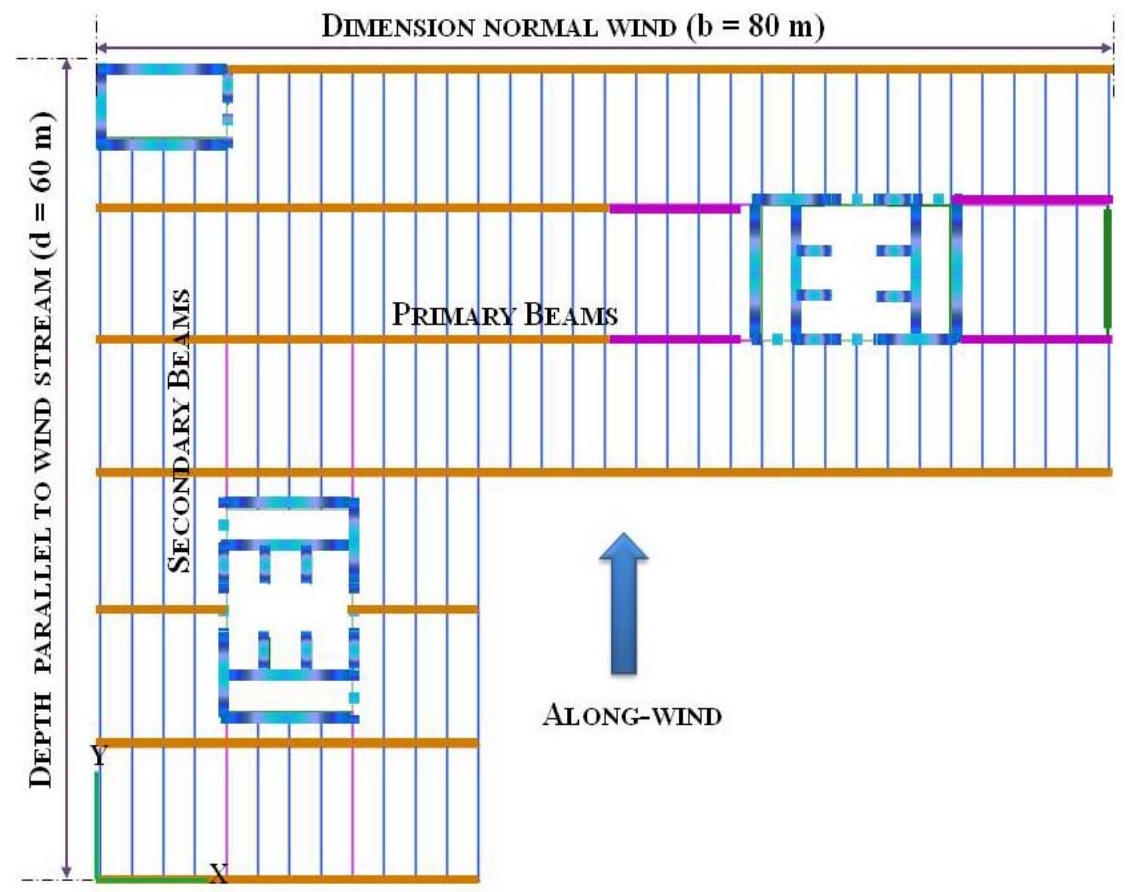

Figure 5. Direction of Wind on L-Shaped Layout
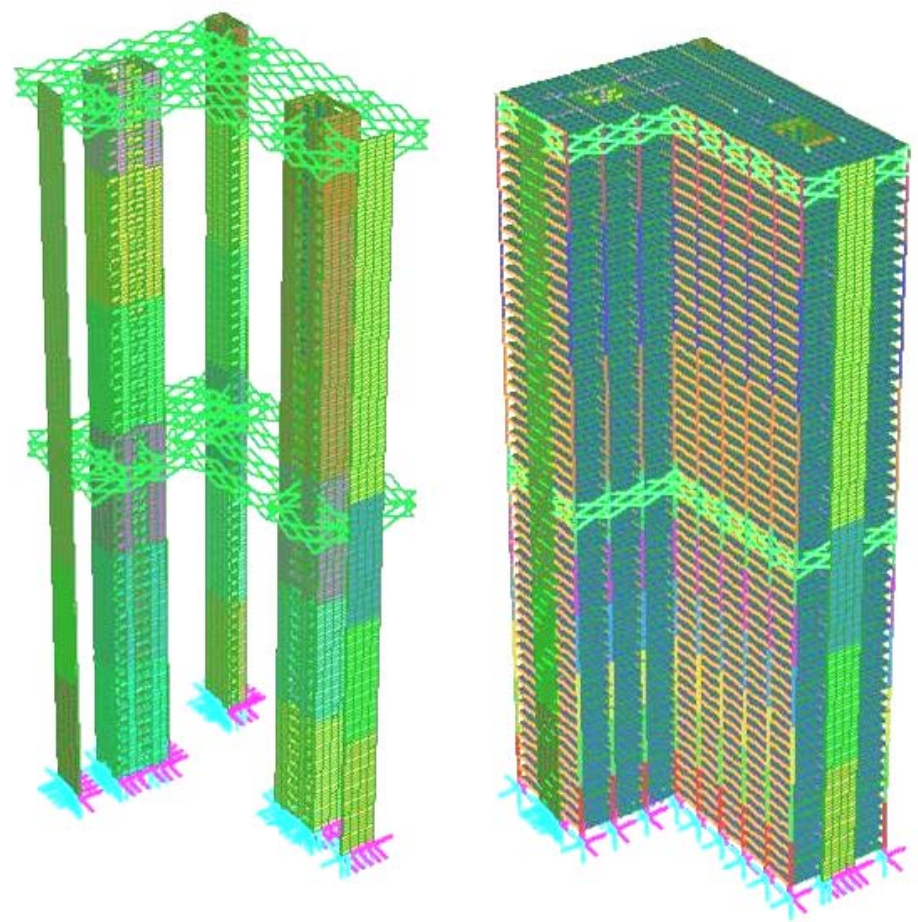

Figure 6. L-Shaped Model Elevation (Shear Wall and Full Model) 


\subsection{Outriggers Provision in Models}

Belt-truss and outriggers are used as secondary bracings for lateral load resistance in conjunction with primary bracings of RCC shear walls. The main focus of this paper is to study the effects of various combinations of belt-truss and outriggers in composite building prototypes.

Many shapes of truss system are available in the market; however, the crucial objective of this study is not the shape of the truss but its location along building height. Therefore, a commonly used system of cross-bracing is adopted. The position of outrigger used in this study are finalised through various model analysis and listed in Table 1. These arrangements are kept same in Rectangular, Octagonal and L-shaped models.

Table 1. Model Arrangements

\begin{tabular}{|c|c|c|}
\hline \multirow{23}{*}{ 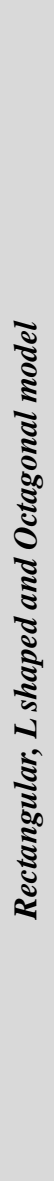 } & Model Title & Model arrangements \\
\hline & 28-Storey & \\
\hline & $28-1$ & Without outrigger \\
\hline & $28-2$ & Outriggers at top \\
\hline & $28-3$ & Outrigger at mid height \\
\hline & 42-storey & \\
\hline & $42-1$ & Without outrigger \\
\hline & $42-2$ & Outrigger at top \\
\hline & $42-3$ & Outrigger at mid-height \\
\hline & $42-4$ & Outrigger at top and mid-height \\
\hline & $42-5$ & Double outrigger at top \\
\hline & $42-6$ & Double outrigger at mid-height \\
\hline & 57-storey & \\
\hline & $57-1$ & Without outrigger \\
\hline & $57-2$ & Outrigger at top \\
\hline & $57-3$ & Outrigger at 2/3 height (level 38) \\
\hline & $57-4$ & Outrigger at mid-height (level 29) \\
\hline & $57-5$ & Outrigger at top and mid-height \\
\hline & $57-6$ & Outrigger at top, mid-height and $2 / 3$ rd height \\
\hline & $57-7$ & Double outrigger at top \\
\hline & $57-8$ & Double outrigger at mid-height \\
\hline & $57-9$ & Double outrigger at $2 / 3$ rd height \\
\hline & $57-10$ & Double outrigger at top and mid-height \\
\hline
\end{tabular}

\section{FRAMING LAYOUT OF MODELS}

Models are framed within the applicability of Australian standards AS1170.2 [11] for the maximum height and horizontal dimensions to satisfy requirement of clause 1.1.

Framing components of models consist of:

a. Composite slab is $120 \mathrm{~mm}$ thick (overall) including $0.75 \mathrm{~mm}$ of corrugated steel sheeting [12]. The transformed properties of composite slab are calculated using Eq. $1 \& 2$. 
Transformed Elastic Modulus of composite Section is given by Eq. 1 :

$$
A_{c} E_{c}+A_{S T} E_{S}=A_{g} E_{T}
$$

Transformed Density of Composite Section is given by Eq. 2 :

$$
A_{c} \gamma_{c}+A_{S T} \gamma_{S}=A_{g} \gamma_{T}
$$

b. Secondary beams are at $2.5 \mathrm{~m} \mathrm{c} / \mathrm{c}$ spacing and structural steel I-sections, selected from design capacity tables of Australian Steel Institute [13].

c. Primary beams are at $10.0 \mathrm{~m} \mathrm{c} / \mathrm{c}$ spacing and structural steel I-sections, selected from design capacity tables of Australian Steel Institute [13].

d. Composite columns are square shaped and placed at $10.0 \mathrm{~m}$ spacing, made up of RCC embedded with structural steel I-section selected from design capacity tables of Australian Steel Institute [13]. Columns are divided into two categories i.e. internal column with load catchment area of $100 \mathrm{~m}^{2}$ / floor and edge columns with load catchment area of $50 \mathrm{~m}^{2} /$ floor. Transformed properties of column are calculated using Eq. $1 \& 2$.

e. Shear walls and core walls are provided as RCC walls and serve as primary bracings. Minimum thicknesses and locations of RCC walls are given to satisfy requirements of building code. Shear walls are the main contributor of models optimisation process. The thicknesses and locations of RCC walls are adjusted for each "run" and "re-run" of model to accomplish desired frequencies and vibrational mode shapes of prototypes.

f. Belt-truss and outriggers are structural steel I-sections selected from design capacity tables of Australian Steel Institute [13] and provided as secondary bracings for lateral loads transfer to RCC shear walls. The varied location of belt-truss and outriggers (Table 1) in different models is the basis of this study.

g. Construction type is "Simple Construction", adopted from Australian standard AS 4100[14]. Moment releases are provided at "beam-to-beam" and "beam-to-column" connections (Figure 7).

h. Fixed support is given to columns and RCC walls at the base of model (Figure 8).

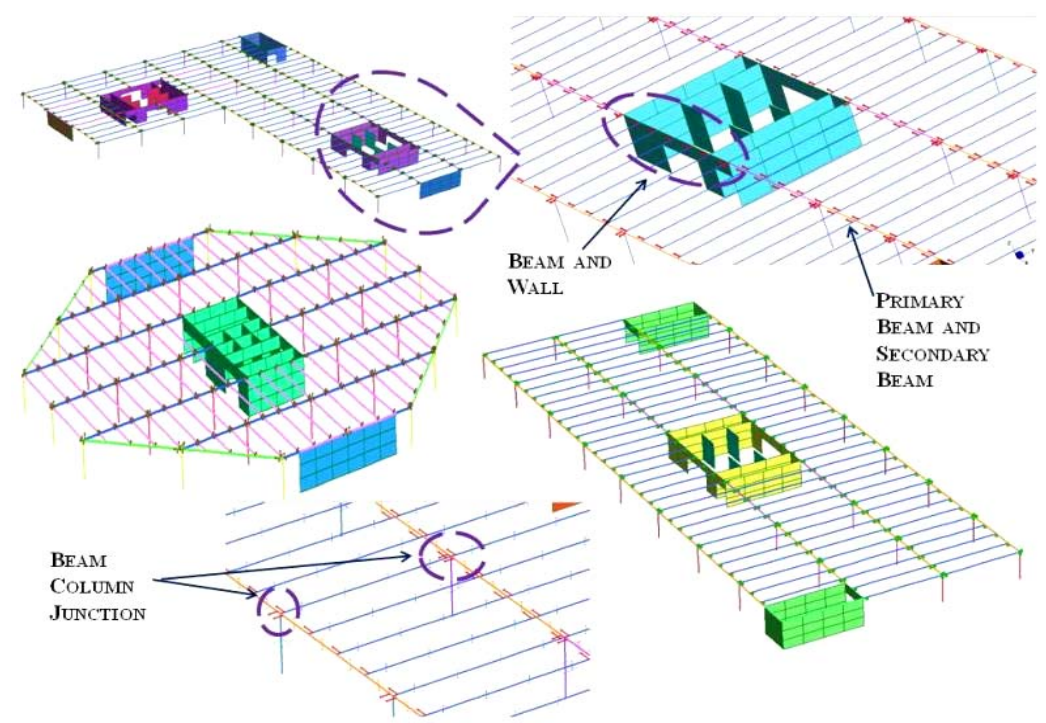

Figure 7. Beam End Releases (Partial Model) 


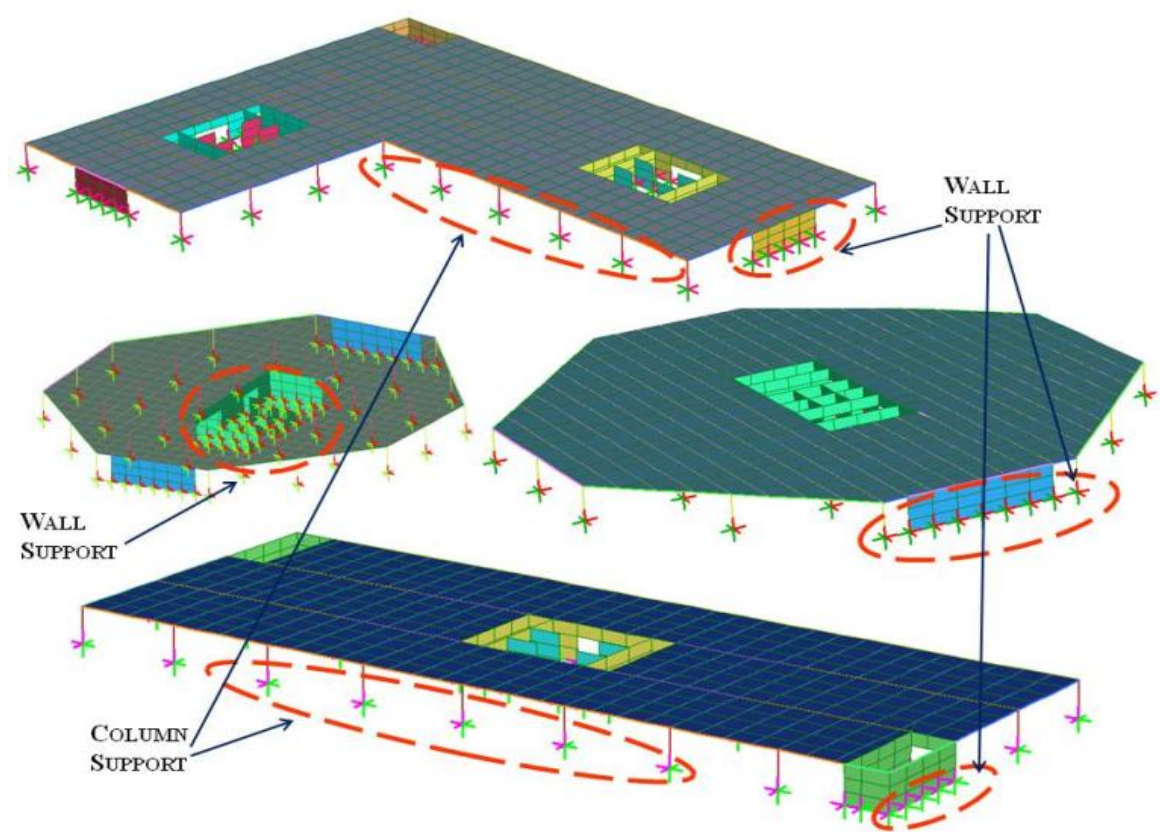

Figure 8. Support at Base (Partial Model)

\section{MODELLING VALIDATION}

The models are analysed by Strand7 R2.4.4 [15] finite element software. Robustness and accuracy of models are verified by comparing values of interior and exterior column reactions with the manually calculated loads. Further; the results of base shear along wind and cross wind are also compared with those evaluated manually to satisfy the reliability and accuracy of models. The validation summary is given for typical models in Table $2 \mathrm{a}, 2 \mathrm{~b}$ and $2 \mathrm{c}$ which showed the difference of values calculated manually and through strand7 is within the general acceptable limits of 5\% to $10 \%$.

Table 2. Model Validation

Table 2 a: Summary of modelling validation for 57- Storey rectangular model $(199.50 \mathrm{~m})$

\begin{tabular}{|l|l|l|l|}
\hline Items & $\begin{array}{l}\text { Manual } \\
\text { Cals }\end{array}$ & Strand7 & Difference \\
\hline Exterior column load $(\mathrm{kN})$ & 11609 & 11816 & $1.866 \%$ \\
\hline Interior column load $(\mathrm{kN})$ & 24259 & 24379 & $0.544 \%$ \\
\hline Base shear - along-wind response $(\mathrm{kN})$ & 4398990 & 4282334 & $2.65 \%$ \\
\hline Base Shear - crosswind $(\mathrm{kN})$ & 3751029 & 3756480 & $0.15 \%$ \\
\hline
\end{tabular}

Table 2b: Summary of modelling validation for 42- Storey L- Shaped model (147.0 m)

\begin{tabular}{|l|c|c|c|}
\hline Items & Manual Cals & Strand7 & Difference \\
\hline Exterior column load $(\mathrm{kN})$ & 8315 & 8363 & $0.57 \%$ \\
\hline Interior column load $(\mathrm{kN})$ & 16929 & 16631 & $1.792 \%$ \\
\hline Base shear - along-wind response $(\mathrm{kN})$ & 2068261 & 2177840 & $5.30 \%$ \\
\hline Base Shear - crosswind $(\mathrm{kN})$ & 1983308 & 1824130 & $8.03 \%$ \\
\hline
\end{tabular}


Table 2c: Summary of modelling validation for 28 - storey octagonal model $(98.0 \mathrm{~m})$

\begin{tabular}{|l|c|c|c|}
\hline Items & Manual Cals & Strand7 & Difference \\
\hline \hline Exterior column load $(\mathrm{kN})$ & 5392 & 5192 & $3.7 \%$ \\
\hline Interior column load $(\mathrm{kN})$ & 9770 & 10008 & $2.44 \%$ \\
\hline Base shear - along-wind response $(\mathrm{kN})$ & 798422 & 733977 & $8.07 \%$ \\
\hline Base Shear - crosswind $(\mathrm{kN})$ & 634895 & 711264 & $10.73 \%$ \\
\hline
\end{tabular}

\section{WIND ACTION FOR MODELS}

Wind actions on any structure or structural component can be "static" or "dynamic" as classified by Australian standard AS1170.2 [11]. The decision of type of actions to be applied on any structure or structural component depends on variables such as frequency, dimensions and site location $[16,17]$.

Australian Standard AS1170.2 [11] recommended that any structure or structural component with frequency less than $1.0 \mathrm{~Hz}$ must be analysed and designed for dynamic wind loads. Models used in this study have frequencies below $1 \mathrm{~Hz}$, therefore; dynamic wind loads are applied in FEM analysis.

\section{APPLICATION OF WIND LOADS ON MODELS}

Wind action is considered as global phenomenon i.e. acting on overall structure because target is to examine the overall structural serviceability performance. Therefore; these forces are applied as "Global Pressure" in kN/m by selecting horizontal beam members on each level in Y-dir. and X-dir. for along-wind and crosswind pressure respectively (Figure 9, Figure $10 \&$ Figure 11).

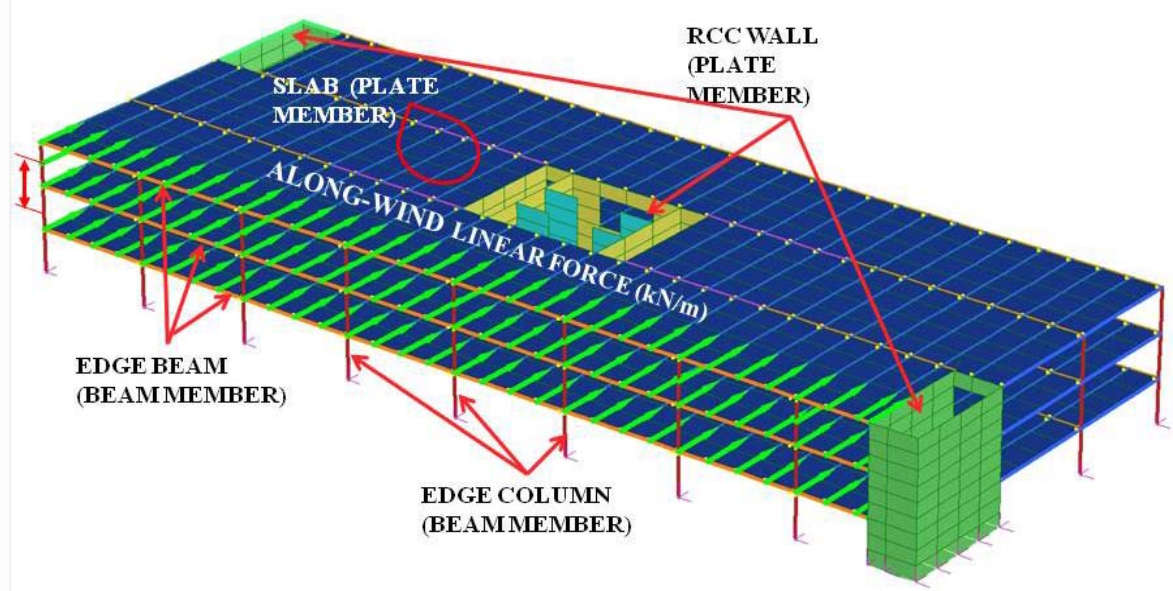

Figure 9. Along-Wind Linear Force on Rectangular Model (Partial Model) 


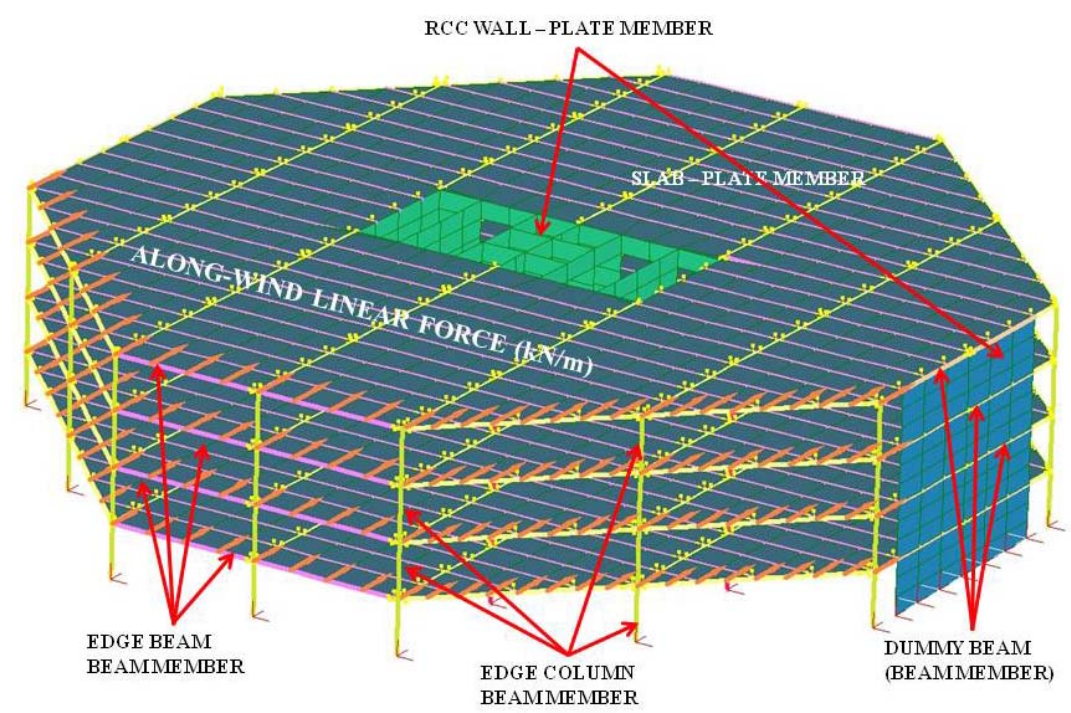

Figure 10. Along-Wind Linear Force on Octagonal Model (Partial Model)

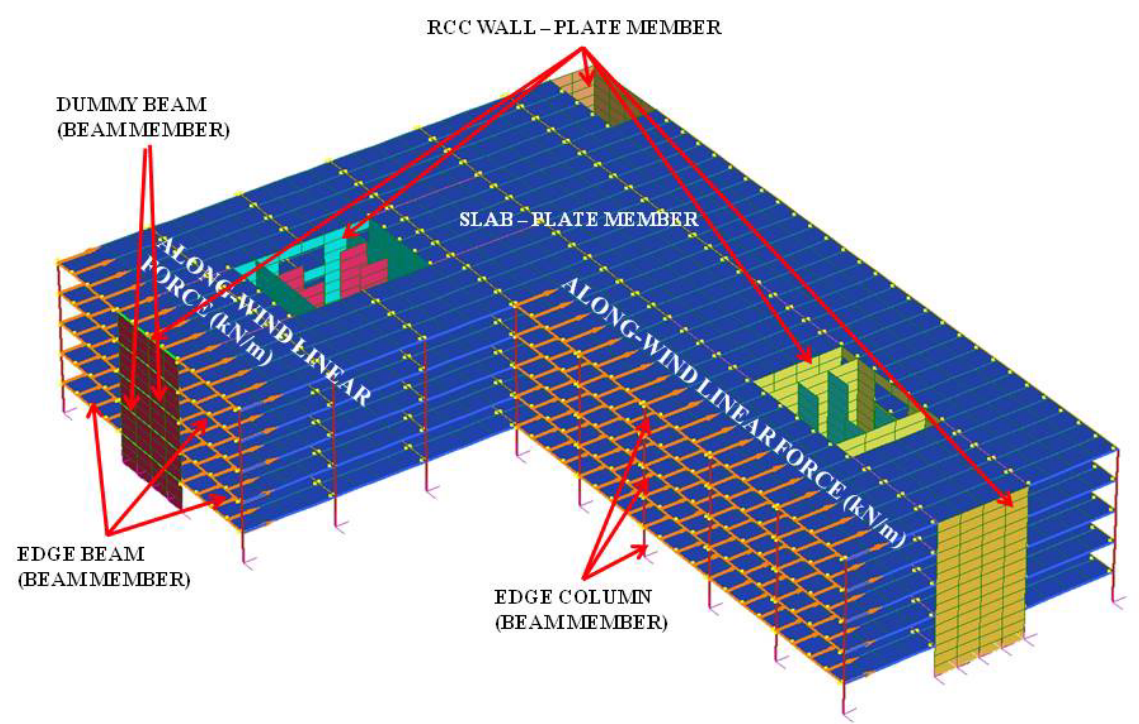

Figure 11. Along-Wind Linear Force on L-Shaped Model (Partial Model)

\section{LOAD COMBINATION}

The load combination used is as per the guidelines of Australian Standard AS1170.1 [18] and is given in Eq. 3 :

$$
\text { Load Combination }=0.5 G+1.0 W x+1.0 W y
$$

In the above equation $\mathrm{G}$ stands for gravitational loads whereas, $W y$ and $W x$ are wind in along wind and crosswind direction respectively. 


\section{RESULTS AND COMPARISON}

Table 3, Table 4 and Table 5 are representing the values of frequency and deflections which are extracted from model analysis results. Along wind and cross wind acceleration calculation was not the scope of this research therefore neglected. But future researcher can assess the performance of the location of outrigger braced system by estimating acceleration of multistorey building.

Table 3. Results for Rectangular Models

\begin{tabular}{|c|c|c|c|c|}
\hline \multicolumn{5}{|c|}{ Rectangular plan models } \\
\hline \multirow{3}{*}{$\begin{array}{l}\text { Model } \\
\text { title }\end{array}$} & \multicolumn{2}{|l|}{ Frequency } & \multicolumn{2}{|c|}{ Deflection at top } \\
\hline & $\begin{array}{c}\text { Mode } 1 \\
\text { (Y-dir) }\end{array}$ & $\begin{array}{r}\text { Mode } 2 \\
\text { (X-dir) }\end{array}$ & $\Delta \mathbf{x}$ & $\Delta \mathbf{Y}$ \\
\hline & $\mathbf{H z}$ & $\mathbf{H z}$ & $\mathbf{m m}$ & $\mathbf{m m}$ \\
\hline $28-1$ & 0.4253 & 0.4532 & 91 & 136 \\
\hline $28-2$ & 0.4466 & 0.4702 & 81 & 122 \\
\hline $28-3$ & 0.4492 & 0.4857 & 78 & 125 \\
\hline $42-1$ & 0.2160 & 0.2466 & 316 & 480 \\
\hline $42-2$ & 0.2314 & 0.2590 & 278 & 411 \\
\hline $42-3$ & 0.2322 & 0.2677 & 269 & 419 \\
\hline $42-4$ & 0.2456 & 0.2788 & 241 & 368 \\
\hline $42-5$ & 0.2428 & 0.2687 & 252 & 369 \\
\hline $42-6$ & 0.2475 & 0.2861 & 237 & 372 \\
\hline $57-1$ & 0.1682 & 0.2071 & 344 & 624 \\
\hline $57-2$ & 0.1745 & 0.2140 & 326 & 592 \\
\hline $57-3$ & 0.1761 & 0.2184 & 318 & 591 \\
\hline $57-4$ & 0.1751 & 0.2176 & 322 & 601 \\
\hline $57-5$ & 0.1806 & 0.2240 & 299 & 556 \\
\hline $57-6$ & 0.1863 & 0.2334 & 275 & 522 \\
\hline $57-7$ & 0.1797 & 0.2206 & 303 & 554 \\
\hline $57-8$ & 0.1812 & 0.2273 & 297 & 563 \\
\hline $57-9$ & 0.1830 & 0.2287 & 290 & 547 \\
\hline $57-10$ & 0.1905 & 0.2392 & 261 & 496 \\
\hline
\end{tabular}

Table 4. Results for Octagonal Model

\begin{tabular}{|c|c|c|c|c|}
\hline \multicolumn{5}{|c|}{ Octagonal plan model } \\
\hline \multirow{3}{*}{$\begin{array}{l}\text { Model } \\
\text { title }\end{array}$} & \multicolumn{2}{|l|}{ Frequency } & \multicolumn{2}{|c|}{ Deflection at top } \\
\hline & $\begin{array}{c}\text { Mode 1 } \\
\text { (Y-dir) } \\
\end{array}$ & $\begin{array}{l}\text { Mode } 2 \\
\text { (X-dir) }\end{array}$ & $\Delta \mathbf{x}$ & $\Delta \mathbf{Y}$ \\
\hline & $\mathrm{Hz}$ & $\mathrm{Hz}$ & $\mathbf{m m}$ & $\mathbf{m m}$ \\
\hline $28-1$ & 0.415875 & 0.486169 & 81 & 110 \\
\hline $28-2$ & 0.415875 & 0.486169 & 81 & 110 \\
\hline $28-3$ & 0.415875 & 0.486169 & 81 & 110 \\
\hline $42-1$ & 0.199592 & 0.268083 & 309 & 496 \\
\hline $42-2$ & 0.236321 & 0.278908 & 264 & 328 \\
\hline $42-3$ & 0.254542 & 0.297667 & 260 & 305 \\
\hline $42-4$ & 0.284011 & 0.307887 & 231 & 227 \\
\hline
\end{tabular}




\begin{tabular}{|l|c|c||c|c||}
\hline \multirow{2}{*}{$\begin{array}{l}\text { Octagonal plan model } \\
\text { Model }\end{array}$} & \multicolumn{2}{|c||}{ Frequency } & \multicolumn{2}{c||}{ Deflection at top } \\
\cline { 2 - 5 } & $\begin{array}{c}\text { Mode 1 } \\
\text { (Y-dir) }\end{array}$ & $\begin{array}{c}\text { Mode 2 } \\
\text { (X-dir) }\end{array}$ & $\Delta \mathbf{x}$ & $\Delta \mathbf{Y}$ \\
\cline { 2 - 5 } & $\mathbf{H z}$ & $\mathbf{H z}$ & $\mathbf{m m}$ & $\mathbf{m m}$ \\
\hline \hline $42-5$ & 0.251109 & 0.284212 & 241 & 278 \\
\hline $42-6$ & 0.285162 & 0.313097 & 233 & 243 \\
\hline $57-1$ & 0.16054 & 0.25698 & 320 & 632 \\
\hline $57-2$ & 0.17992 & 0.26406 & 290 & 481 \\
\hline $57-3$ & 0.19174 & 0.26836 & 284 & 437 \\
\hline $57-4$ & 0.1867 & 0.26629 & 293 & 475 \\
\hline $57-5$ & 0.20284 & 0.27226 & 268 & 381 \\
\hline $57-6$ & 0.22038 & 0.28032 & 248 & 316 \\
\hline $57-7$ & 0.18935 & 0.2697 & 270 & 419 \\
\hline $57-8$ & 0.20499 & 0.20499 & 272 & 393 \\
\hline $57-9$ & 0.21042 & 0.27729 & 261 & 356 \\
\hline $57-10$ & 0.22654 & 0.28414 & 237 & 295 \\
\hline
\end{tabular}

Table 5. Results for L-Shaped Model

\begin{tabular}{|l|c|c||c|c||}
\hline \multirow{2}{*}{\begin{tabular}{c}
\multirow{2}{*}{$\begin{array}{c}\text { Model } \\
\text { title }\end{array}$} \\
\cline { 2 - 5 }
\end{tabular}} & $\begin{array}{c}\text { Mode 1 } \\
\text { (Y-dir) }\end{array}$ & $\begin{array}{c}\text { Mode 2 } \\
\text { (X-dir) }\end{array}$ & $\Delta \mathbf{x}$ & $\Delta \mathbf{~}$ \\
\cline { 2 - 5 } & Hz & Hz & mm & mm \\
\hline \hline $28-1$ & 0.52037 & 0.562095 & 37 & 82 \\
\hline $28-2$ & 0.541861 & 0.585756 & 33 & 75 \\
\hline $28-3$ & 0.549083 & 0.592318 & 33 & 76 \\
\hline $42-1$ & 0.272314 & 0.293305 & 140 & 317 \\
\hline $42-2$ & 0.288653 & 0.310919 & 120 & 284 \\
\hline $42-3$ & 0.293108 & 0.316163 & 120 & 285 \\
\hline $42-4$ & 0.306936 & 0.331709 & 106 & 260 \\
\hline $42-5$ & 0.300782 & 0.324645 & 106 & 260 \\
\hline $42-6$ & 0.314111 & 0.340426 & 104 & 256 \\
\hline $57-1$ & 0.194008 & 0.208954 & 247 & 594 \\
\hline $57-2$ & 0.204443 & 0.218722 & 218 & 538 \\
\hline $57-3$ & 0.20871 & 0.222793 & 215 & 529 \\
\hline $57-4$ & 0.205941 & 0.220009 & 222 & 544 \\
\hline $57-5$ & 0.215409 & 0.229007 & 199 & 499 \\
\hline $57-6$ & 0.226422 & 0.239875 & 180 & 462 \\
\hline $57-7$ & 0.212267 & 0.226722 & 197 & 501 \\
\hline $57-8$ & 0.216236 & 0.229961 & 204 & 506 \\
\hline $57-9$ & 0.220845 & 0.23482 & 192 & 483 \\
\hline $57-10$ & 0.231927 & 0.246057 & 168 & 441 \\
\hline
\end{tabular}




\subsection{Graphical Representation of Output}

\subsubsection{8-storeys}

Deflections and frequencies of 28-storeys models are compared in Figure 12 and Figure 13.

\section{Fundamental Frequency of 28- Storeys Models}

respectively. The straight line of octagonal model shows that insertions of outriggers have no effect on deflections. In octagonal model deflection in X-dir. is $80 \mathrm{~mm}$ while in Y-dir. is $110 \mathrm{~mm}$ because of core wall layout contribution of rigidity is higher in X-dir. than in Y-dir.

Graph is similar in L-shaped model for frequency and deflection with higher values in Y-dir. The deflection values are almost unchanged in 28-2 and 28-3 in X-dir. and Y-dir. frequency is also slightly varied in $\mathrm{X}$-axis and $\mathrm{Y}$-axis.

Y-dir. in Rectangular model showed trivial reverse curve in deflection. This stipulates that outriggers at top provide better deflection control.

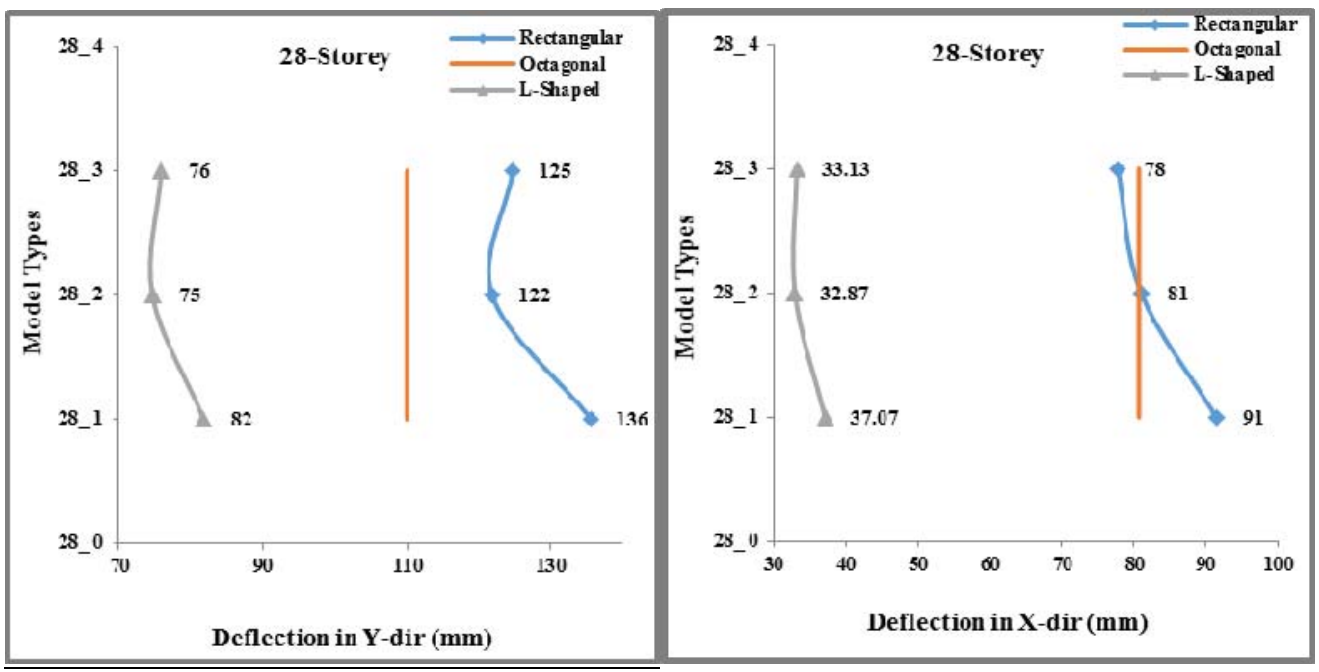

Figure 12. Deflection Comparison of 28- Storeys Models
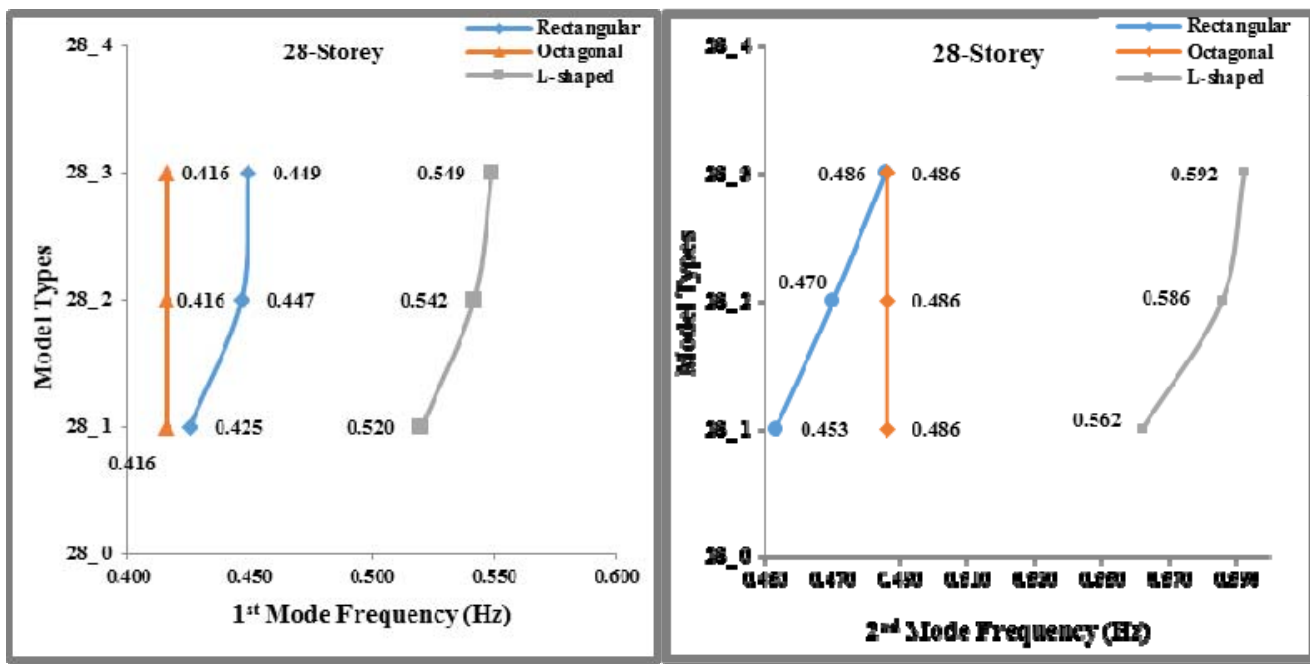
Figure 13. Fundamental Frequency of 28- Storeys Models

\subsubsection{2-storey}

Six variations of 42-storey models with various arrangements of belt-truss and outriggers are compared in Figure 14 and Figure 15. In octagonal 42-4 model, curve reversed and moved toward right. Although; 42-2 and 42-5 have two outriggers levels but their arrangement effects on deflection.

Rectangular model has reversed curvature between 42-2 and 42-3 which showed that outrigger at top is more effective than in middle. The values of deflection in X-dir. are very similar in Octagonal and Rectangular model whereas; L-shaped model has markedly less deflection. The planar X-dimension of Rectangular and L-shaped models is $80 \mathrm{~m}$. But the shear wall contribution in L-shaped model is higher than in rectangular model.

The frequency variation in octagonal model showed the outrigger affectivity. The $2^{\text {nd }}$ mode frequency in all three plan options have reverse curve at 42-5. 42-4, 42-5 and 42-6 all have double outriggers with different arrangement. The least effective is double outrigger at top i.e. 42-5. Provision of mid-height outrigger has better effects due to the reversal of curvature at mid-height.

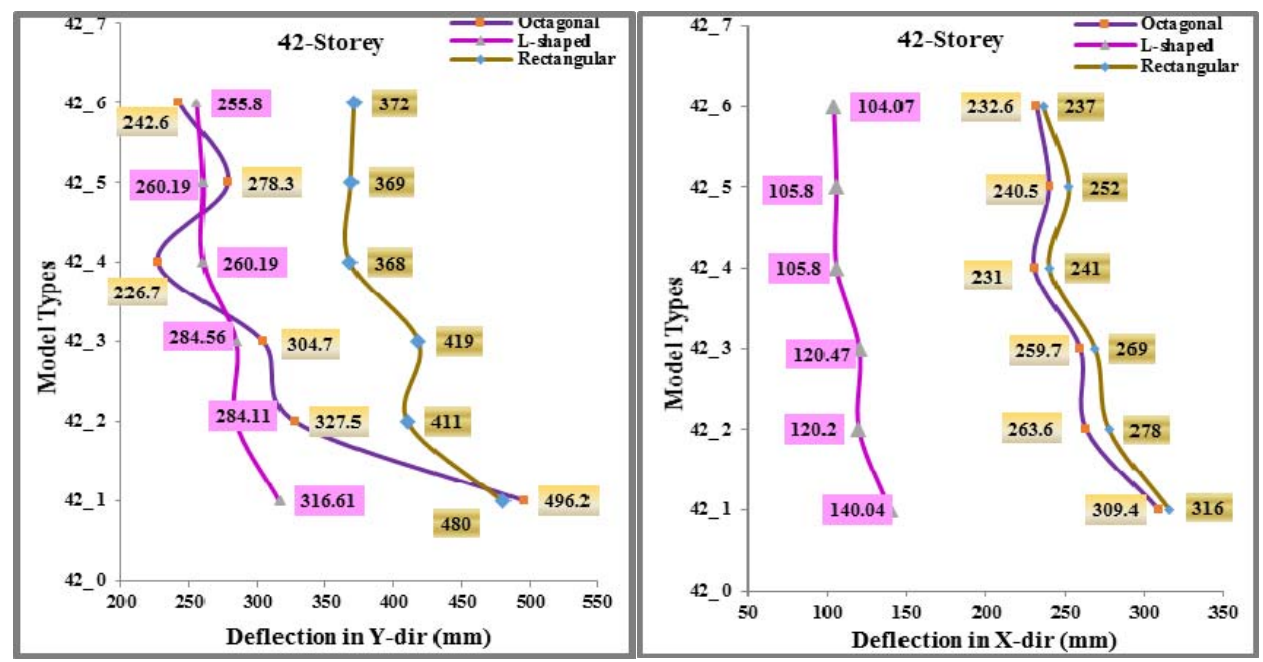

Figure 14. Deflection Comparison of 42- Storeys Models.
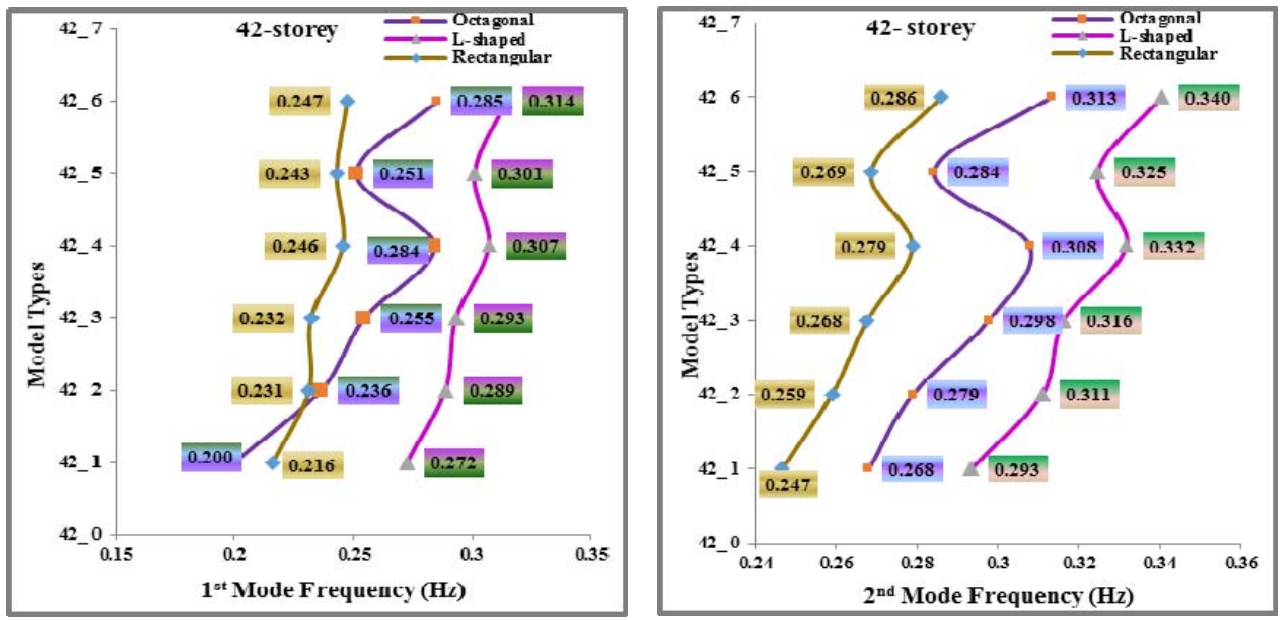
Figure 15. Fundamental Frequency of 42- Storeys Models

\subsubsection{7-storeys}

Error! Reference source not found. shows deflection curve for 10 models of 57-storeys. Generally; a sharp decline in deflection is observed as one outrigger level is inserted at top floor. This trend continued up to 57-3 which has outriggers at $2 / 3^{\text {rd }}$ height, however; graph reversed at $57-4$ as the outrigger position has changed to mid-height of the model. Addition of outrigger at two positions i.e. at top and mid-height (57-5), again lead to decay of frequency.

The options 57-5, 57-7, 57-8 and 57-9 all have two outrigger levels but minimum deflection is achieved in both axes of 57-9 which is double outrigger at $2 / 3^{\text {rd }}$ height. The sharpest curve is for octagonal model as seen in Error! Reference source not found. and milder curve is of rectangular plan model. The strident increase of frequency by inserting three outrigger levels (i.e. 57-6) and then an abrupt descent in values by providing double outrigger at top (57-7) indicates that frequency is affected by placement of bracings.
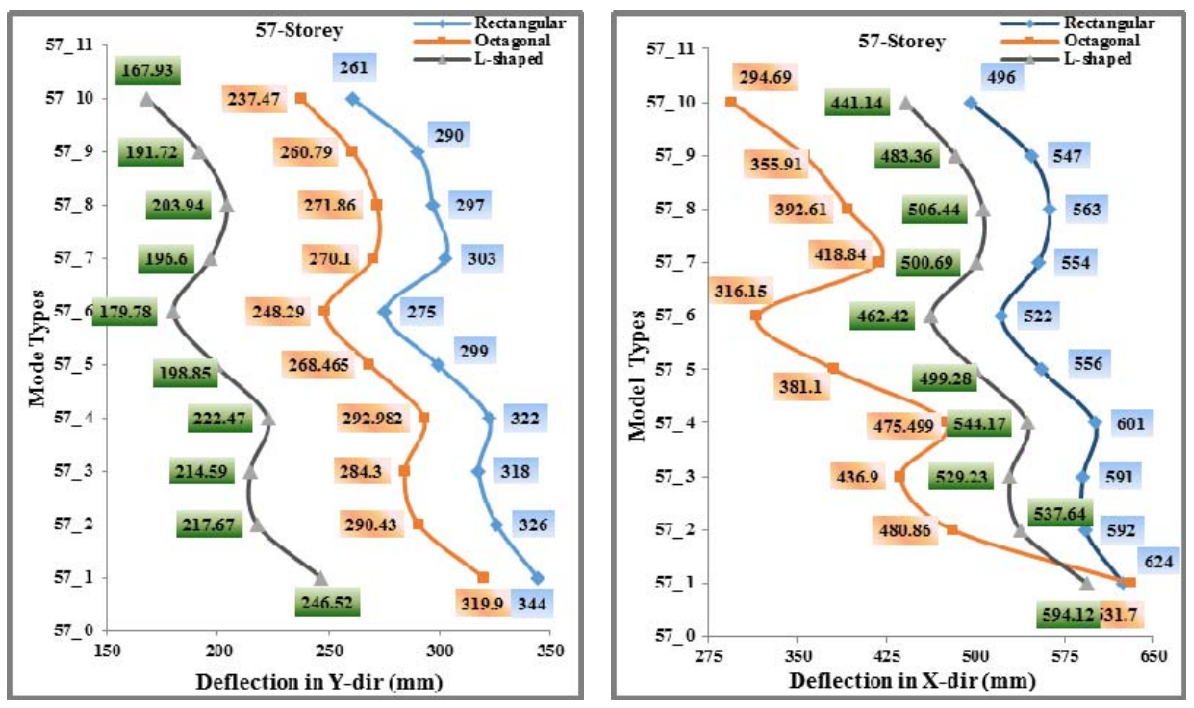

Figure 16. Deflection Comparison of 57- Storeys Models
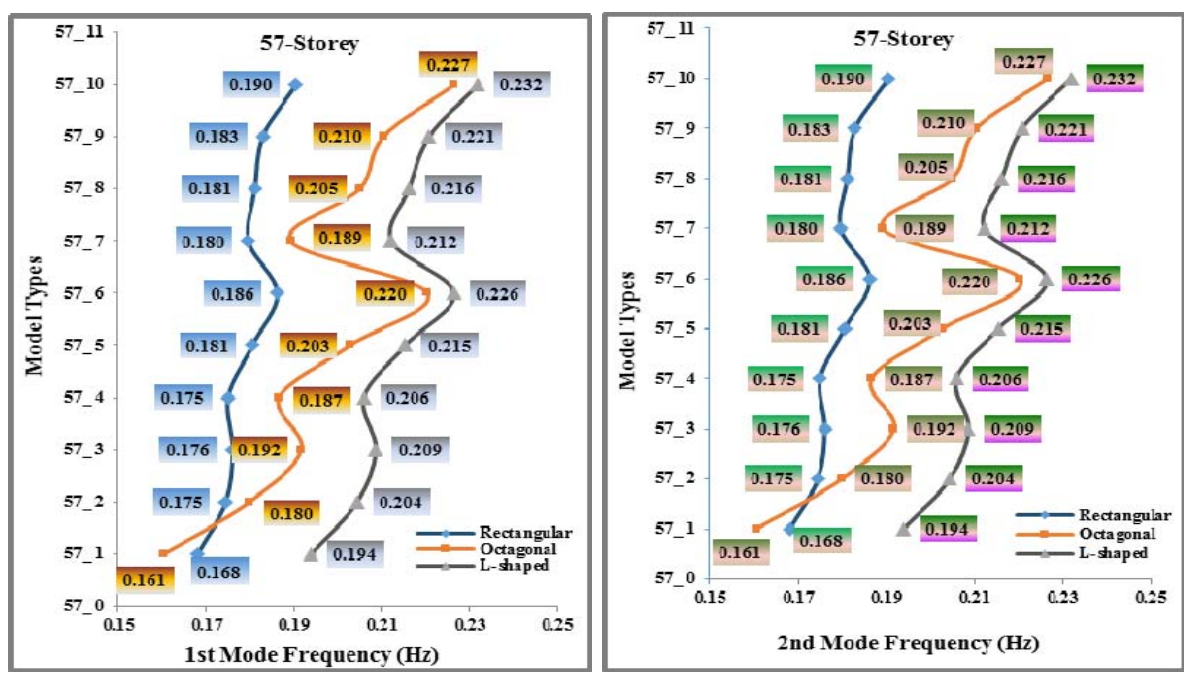
Figure 17. Frequency Comparison of 57- Storeys Models

\subsection{Percentage Reductions in Deflection}

The relationship of percentage deflection decline in various models in comparison of model "without belt-truss and outriggers" is given by Eq. 4. The values of lateral displacement decrement are provided in Table 6.

$$
\% \Delta_{(\text {reduction })}=\frac{\Delta_{(\text {model without outrigger })}-\Delta_{(\text {any model arrangement })}}{\Delta_{(\text {model without outrigger })}} \times 100
$$

28 -storey octagonal model is not affected by any of the outrigger arrangements. Rectangular model has least value in 28-2 while L-shaped has lowest value in 28-3. Rectangular and octagonal models have maximum reduction in deflection in 42-6 for X-axis and 42-4 for Y-axis. L-shaped model has maximum deflection reduction in 42-6 in both axes. In all 57-storeys maximum reduction of deflection is obtained in 57-10.

Table 6. Percentage Reduction in Deflection

\begin{tabular}{|c|c|c|c|c|c|c|}
\hline \multicolumn{7}{|c|}{$\%$ Reduction in deflection } \\
\hline \multirow{2}{*}{ Model title } & \multicolumn{2}{|c|}{ Rectangular } & \multicolumn{2}{|c|}{ Octagonal } & \multicolumn{2}{|c|}{ L-shaped } \\
\hline & $\% \Delta x$ & $\% \Delta \mathbf{Y}$ & $\% \Delta x$ & $\% \Delta \mathrm{Y}$ & $\% \Delta x$ & $\% \Delta \mathrm{Y}$ \\
\hline $28-1$ & $0 \%$ & $0 \%$ & $0 \%$ & $0 \%$ & $0 \%$ & $0 \%$ \\
\hline $28-2$ & $11.50 \%$ & $10.20 \%$ & $0 \%$ & $0 \%$ & $11.30 \%$ & $8.70 \%$ \\
\hline $28-3$ & $15.10 \%$ & $8.10 \%$ & $0 \%$ & $0 \%$ & $10.60 \%$ & $7.20 \%$ \\
\hline $42-1$ & $0 \%$ & $0 \%$ & $0 \%$ & $0 \%$ & $0 \%$ & $0 \%$ \\
\hline $42-2$ & $12.10 \%$ & $14.60 \%$ & $14.80 \%$ & $34.00 \%$ & $14.20 \%$ & $10.30 \%$ \\
\hline $42-3$ & $14.90 \%$ & $12.80 \%$ & $16.10 \%$ & $38.60 \%$ & $14.00 \%$ & $10.10 \%$ \\
\hline $42-4$ & $23.90 \%$ & $23.40 \%$ & $25.30 \%$ & $54.30 \%$ & $24.50 \%$ & $17.80 \%$ \\
\hline $42-5$ & $20.20 \%$ & $23.20 \%$ & $22.30 \%$ & $43.90 \%$ & $24.50 \%$ & $17.80 \%$ \\
\hline $42-6$ & $25.20 \%$ & $22.70 \%$ & $24.80 \%$ & $51.10 \%$ & $25.70 \%$ & $19.20 \%$ \\
\hline $57-1$ & $0 \%$ & $0 \%$ & $0 \%$ & $0 \%$ & $0 \%$ & $0 \%$ \\
\hline $57-2$ & $5.50 \%$ & $5.20 \%$ & $9.20 \%$ & $23.90 \%$ & $11.70 \%$ & $9.50 \%$ \\
\hline $57-3$ & $7.80 \%$ & $5.40 \%$ & $11.10 \%$ & $30.80 \%$ & $13.00 \%$ & $10.90 \%$ \\
\hline $57-4$ & $6.50 \%$ & $3.80 \%$ & $8.40 \%$ & $24.70 \%$ & $9.80 \%$ & $8.40 \%$ \\
\hline $57-5$ & $13.10 \%$ & $11.00 \%$ & $16.10 \%$ & $39.70 \%$ & $19.30 \%$ & $16.00 \%$ \\
\hline $57-6$ & $20.10 \%$ & $16.50 \%$ & $22.40 \%$ & $50.00 \%$ & $27.10 \%$ & $22.20 \%$ \\
\hline $57-7$ & $12.10 \%$ & $11.40 \%$ & $15.60 \%$ & $33.70 \%$ & $20.20 \%$ & $15.70 \%$ \\
\hline $57-8$ & $13.80 \%$ & $9.90 \%$ & $15.00 \%$ & $37.80 \%$ & $17.30 \%$ & $14.80 \%$ \\
\hline $57-9$ & $15.80 \%$ & $12.40 \%$ & $18.50 \%$ & $43.70 \%$ & $22.20 \%$ & $18.60 \%$ \\
\hline $57-10$ & $24.30 \%$ & $20.60 \%$ & $25.80 \%$ & $53.30 \%$ & $31.90 \%$ & $25.70 \%$ \\
\hline
\end{tabular}

\subsection{Percentage Frequency Increments}

The frequencies in Table 7 shows very similar trend for all three model heights and the highest frequency value is achieved with maximum number of belt-truss and outriggers floors. These are calculated according to Eq. 5 .

$$
\% f_{(\text {increment })}=\frac{f_{(\text {any model arrangement })}-f_{(\text {model without outrigger })}}{f_{(\text {model without outrigger })}} \times 100
$$


The frequency is a characteristic of stiffness, more stiffness higher frequency however; frequency also get affected by belt-truss and outriggers placement. For instance; 57-5, 57-7 57-8 and 57-9 have two outrigger floors at various levels. Theoretically the overall stiffness is same in these three options, however; maximum percentage increment is attained in 57-9, which is double outrigger level at $2 / 3^{\text {rd }}$ height of building. The placement of belt-truss and outriggers change the centre of gravity of model and impact on vertical curvature which in turn affect the frequency of model.

In 42-storeys, comparison of 42-4, 42-5 and 42-6 showed that the maximum frequency increment is obtained in 42-6. Although; three of these have the same mass but different truss placement changes the centre of gravity of model and results in changed frequency.

Table 7. Percentage Increment in Frequency

\begin{tabular}{|c|c|c|c|c|c|c|}
\hline \multicolumn{7}{|c|}{$\%$ Increase in frequency values } \\
\hline \multirow{2}{*}{$\begin{array}{l}\text { Model } \\
\text { title }\end{array}$} & \multicolumn{2}{|c|}{ Rectangular } & \multicolumn{2}{|c|}{ Octagonal } & \multicolumn{2}{|c|}{ L-shaped } \\
\hline & $\% f_{1 s t}$ & $\% f_{2 n d}$ & $\% f_{1 s t}$ & $\% f_{2 n d}$ & $\% f_{1 s t}$ & $\% f_{2 n d}$ \\
\hline $28-1$ & $0.00 \%$ & $0.00 \%$ & $0 \%$ & $0 \%$ & $0.00 \%$ & $0.00 \%$ \\
\hline $28-2$ & $5.00 \%$ & $3.76 \%$ & $0 \%$ & $0 \%$ & $4.13 \%$ & $4.21 \%$ \\
\hline $28-3$ & $5.62 \%$ & $7.17 \%$ & $0 \%$ & $0 \%$ & $5.52 \%$ & $5.38 \%$ \\
\hline $42-1$ & $0 \%$ & $0 \%$ & $0 \%$ & $0 \%$ & $0 \%$ & $0 \%$ \\
\hline $42-2$ & $7.16 \%$ & $5.00 \%$ & $18.40 \%$ & $4.04 \%$ & $6.00 \%$ & $6.01 \%$ \\
\hline $42-3$ & $7.51 \%$ & $8.53 \%$ & $27.53 \%$ & $11.04 \%$ & $7.64 \%$ & $7.79 \%$ \\
\hline $42-4$ & $13.72 \%$ & $13.05 \%$ & $42.30 \%$ & $14.85 \%$ & $12.71 \%$ & $13.09 \%$ \\
\hline $42-5$ & $12.45 \%$ & $8.95 \%$ & $25.81 \%$ & $6.02 \%$ & $10.45 \%$ & $10.69 \%$ \\
\hline $42-6$ & $14.60 \%$ & $15.99 \%$ & $42.87 \%$ & $16.79 \%$ & $15.35 \%$ & $16.07 \%$ \\
\hline $57-1$ & $0.00 \%$ & $0.00 \%$ & $0.00 \%$ & $0.00 \%$ & $0.00 \%$ & $0.00 \%$ \\
\hline $57-2$ & $3.77 \%$ & $3.34 \%$ & $12.07 \%$ & $2.76 \%$ & $5.38 \%$ & $4.67 \%$ \\
\hline $57-3$ & $4.69 \%$ & $5.46 \%$ & $19.44 \%$ & $4.43 \%$ & $7.58 \%$ & $6.62 \%$ \\
\hline $57-4$ & $4.08 \%$ & $5.06 \%$ & $16.30 \%$ & $3.62 \%$ & $6.15 \%$ & $5.29 \%$ \\
\hline $57-5$ & $7.36 \%$ & $8.15 \%$ & $26.35 \%$ & $5.95 \%$ & $11.03 \%$ & $9.60 \%$ \\
\hline $57-6$ & $10.74 \%$ & $12.68 \%$ & $37.28 \%$ & $9.08 \%$ & $16.71 \%$ & $14.80 \%$ \\
\hline $57-7$ & $6.84 \%$ & $6.51 \%$ & $17.95 \%$ & $4.95 \%$ & $9.41 \%$ & $8.50 \%$ \\
\hline $57-8$ & $7.71 \%$ & $9.75 \%$ & $27.69 \%$ & $6.73 \%$ & $11.46 \%$ & $10.05 \%$ \\
\hline $57-9$ & $8.78 \%$ & $10.41 \%$ & $31.07 \%$ & $7.90 \%$ & $13.83 \%$ & $12.38 \%$ \\
\hline $57-10$ & $13.25 \%$ & $15.50 \%$ & $41.11 \%$ & $10.57 \%$ & $19.55 \%$ & $17.76 \%$ \\
\hline
\end{tabular}

\section{CONCLUSIONS}

This study investigated the behaviour of multi-storey composite buildings when subjected to cyclonic wind loads with different combination of steel belt-truss and outriggers for different plan layouts and for different heights of the building. The results demonstrate that wind action is responsive to the number and placement of belt-truss and outriggers as well as to the different plan layout and height of the building. The findings of the investigation can be summarizes as:

- $\quad 28$-storey provided best result with the addition of bracings at top level of model in three plan layout.

- $\quad$ Provision of single outrigger level in 42-storey has varied outcome in three different plans for single outrigger option. However; provision of single level outrigger at mid-height of model is more desired option. 
- In double outrigger option, provision of double level of outrigger at mid-height in 42-storey provide maximum reduction of lateral deflection.

- $\quad$ In 57-storey it is found out that if one floor of outrigger is required to be placed in building than provision of one level outrigger at $2 / 3^{\text {rd }}$ height (measured from ground level) is the best option.

- In case of double belt-truss and outriggers levels in 57-storey model, the provision of secondary outrigger at $2 / 3^{\text {rd }}$ height (measured from ground level) is the most suitable alternative.

- $\quad$ Three single level outrigger at top of model, $2 / 3^{\text {rd }}$ height from base and mid-height of building is more appropriate than providing two double outrigger levels.

\section{NOTATION}

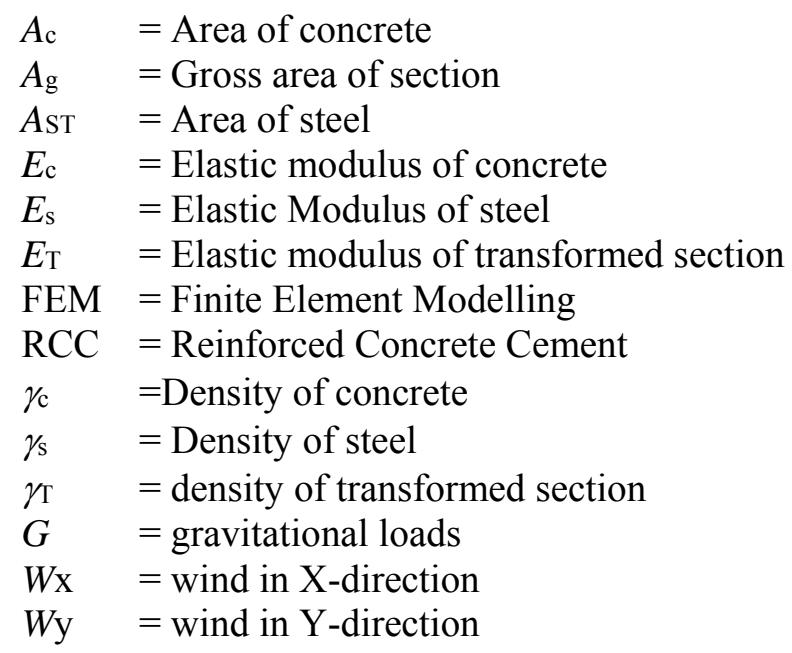

\section{REFERENCES}

[1] Nanduri, P.M.B., Raj, Kiran., Suresh, B., Hussain, M.D. and Ihtesham., "Optimum Position of Outrigger System for High-rise Reinforced Concrete Buildings under Wind and Earthquake Loadings", American Journal of Engineering Research (AJER), 2013, Vol. 2, No. 8, pp. 76-89.

[2] Chung, Y.K., "Optimization of Outrigger Locations in Tall Buildings Subjected to Wind Loads", Masters Research Thesis, 2010,-School of Civil and Environmental Engineering, The University of Melbourne.

[3] Kian, P.S. and Siahaan, F.T., "The Use of Outrigger and Belt Truss System for High-rise Concrete Buildings", Dimensi Teknit Sipil, 2001, Vol. 3, No. 1, pp. 36-41.

[4] Hoenderkamp, J.C.D., and Bakker, C.M., "Analysis of High-rise Braced Frames with Outriggers", Journal of Structural Design of Tall and Special Buildings, 2003, Vol. 12, pp. 335-350.

[5] Hoenderkamp, J.C.D., "Second Outrigger at Optimum Location on High-rise Shear Wall", Journal of Structural Design of Tall and Special Buildings, 2007, Vol. 17, pp. 619-634.

[6] Lee, J., Bangi, M. and Kim, J., "An Analytical Model for High-rise Wall-frame Structures with Outriggers", Journal of Structural Design of Tall and Special Buildings, 2008, Vol. 17, pp. 839-851. 
[7] Lee, J., Park, D., Lee, K., and Ahn, N., "Geometric Nonlinear Analysis of Tall Building Structures with Outriggers", Structural Design of Tall and Special Buildings, 2013, Vol. 22, pp. 454-470.

[8] Taranath, B.S., "Structural Analysis and Design of Tall Buildings: Steel and Composite Construction", CRC Press 2011, Print ISBN: 978-1-4398-5089-3, eBook ISBN: 978-1-4398-5090-9, 2012.

[9] Taranath, B.S., "Wind and Earthquake Resistant Buildings: Structural Analysis and Design", CRC Press 2004, Print ISBN: 978-0-8247-5934-6, eBook ISBN: 978-0-8493-3809-0, 2005.

[10] Rahgozar, R. and Sharifi, Y., "An Approximate Analysis of Framed Tube, Shear Core and Belt Truss in High-rise Building", Struct. Design Tall Spec Build, 2009, Vol. 18, pp. 607-624.

[11] AS1170.2., "Structural Design Actions: part 2 - Wind Actions (AS/NZS 1170.2:2011)", 2011, Retrieved from http://www.saiglobal.com/

[12] Lysaght Bondek., "Structural Steel Decking Syaytem Design and Construction Manual", Bluescope Steel Limited, 2012, Retrieved from http://www.bluescopesteel.com.au/ files/dmfile/BondekDesignAnd ConstructionManualJune2012.pdf

[13] Australian Steel Institute, "Design Capacity Tables for Structural Steel", Volume 1- Open Sections [ $5^{\text {th }}$ ed.], 2009, Sydney, NSW: ASI Publishing.

[14] AS4100, "Steel Structures", Australian Standard. 1998, Retrieved from http://www.saiglobal.com.ezp01.library.qut.edu.au/online/autologin.asp.

[15] Strand7 Release 2.4.4., "Strand7 Pty Ltd", 2011, Copyright Strand7 Pty Ltd. Retrieved from http://www.strand7.com/.

[16] Fawzia, S., Nasir, A. and Fatima,T., "Study of the Effectiveness of Outrigger System for High-rise Composite Buildings for Cyclonic Region", Proceedings of the World Academy of Science, Engineering and Technology, Phuket, Thailand, 2011, pp. 937-945.

[17] Fawzia, S. and Fatima, T., "Deflection Control in Composite Building by Using Belt Truss and Outrigger System", Proceedings of the 2010 World Academy of Science, Engineering and Technology conference, Singapore 2010, pp. 25-27.

[18] AS 1170.1., "Structural Design Actions Part 1: Permanent, Imposed and Other Actions (AS/NZS 1170.1:2002)", 2002, Retrieved from http://www.saiglobal.com/. 